\title{
The Technologization of a Social Cinema as a Tool of Social Work
}

\section{H. Muradkhanian}

Taras Shevchenko National University of Kyiv, Ukraine

Corresponding author. E-mail: Muradhanian@gmail.com

Paper received 18.11.17; Revised 22.11.17; Accepted for publication 25.11.17.

https://doi.org/10.31174/SEND-HS2017-147V25-11

Abstract. This article explores opportunities and perspectives of using social cinema as a social work tool. The author reveals a definition of the social cinema, analyses a development of the phenomenon of the social cinema in historical context. The article explores main characteristics, types and forms of the social cinema, it socio-psychological influence on different client groups of social work. The author describes place and practical importance of the social cinema in social work.

Keywords: social cinema, social work, client groups, population, tool of a social work, technologization.

Introduction. Today social work is on the way of big transformation and development in Ukraine. We need new tools of practical work with different groups of population and clients of social work. Social cinema can become a powerful instrument of highlighting actual social problems, informing a population and preventing different negative situations in society. There are no scientific researches of social cinema in social work or social psychology yet. That is why we have to define a term "social cinema", to analyze and describe it for using social cinema as a tool of social work.

Brief overview of related publications. Social cinema was explored by the theorists and cinema historians Cesare Zavattini, Georges Sadoul, Andre Bazin and Siegfried Kracauer. In sociology, social cinema was a subject of scientific researches by Mikhail Zhabsky and Russell Middleton. In history social cinema is explored by Kay Sloan. William B. Russell explores social cinema in pedagogical approach.

The article aim is to reveal opportunities of social cinema as an instrument of socio-psychological changes that can be used by specialists in social work.

Methods. We used theoretical methods of analysis, comparison, classification and empirical methods of questioning, content analysis and an unstructured interview for this research.

Results and discussion. The history of cinematography begins from XIX century when first films were maken and perceived as a type of entertaiment. Cinematography began to perform a social function since big social disasters that spread throughout the world. The First World War became a checkpoint for forming sociooriented films. Cinema began to highlight actual social problems, to inform society about war situation and to form public opinion and patriotic moods of population.

Since then, films began to focus on actual social issues increasingly and formed a separate genre of cinematography - social cinema. So, social cinema is a genre of cinematography which main task is to highlight actual social problems for changing a situation in the society.

Today social cinema includes feature and documentary films, full-length and short films from different countries all over the world. Social cinema can be a powerful instrument of social work because it has many advantages of highlighting different social problems.

Table 1. Advantages of cinema as a way to highlight social issues

\begin{tabular}{|c|c|r|}
\hline o & Advantages & Content \\
\hline 1. & $\begin{array}{c}\text { Visual perception } \\
\text { of information }\end{array}$ & $\begin{array}{r}\text { - to trigger more vivid emotions, empathy, to dive into the situation; } \\
\text { - the easiest way of perception and data assimilation; }\end{array}$ \\
\hline 2. & $\begin{array}{c}\text { Modeling of life } \\
\text { situations }\end{array}$ & $\begin{array}{r}\text { - an opportunity to look at the problem from the side; } \\
\text { - the possibility of "living inside the problem", to become a hero of the film, to feel } \\
\text { his emotions and to get new experience; }\end{array}$ \\
3. & $\begin{array}{r}\text { Attracting a wide } \\
\text { audience }\end{array}$ & - to understand better different categories of the population, their behavior, reactions; \\
\hline
\end{tabular}

Cinema gives an opportunity of visual perception of information. Films are an essential part of life and popular culture. An average student spends over 7 hours a day using media. Film has real-life applications and is relevant to young people everyday lives [5]. Therefore, it is very easy and fast way to get new knowledge about some social problems and to trigger vivid emotions and empathy from target audience using films.

Cinema also can model different life situations. This characteristic gives an opportunity to dive into the film, to feel film's characters and to understand their actions. Thus, an audience receives new life experience in a safe way. After the screening, you can understand better different categories of population, especially people in difficult life circumstances, to feel empathy for them.

In addition, cinema can attract a wide audience. Thousands people all over the country can watch a film at the same time on a TV screen or at cinema theatres. So films influence on all groups of population, form a public opinion and a social consciousness.

Social films show social issues of different client groups of social work. For using social cinema as a tool of professional work, we have to name these client groups which socio-psychological problems are revealed in films. Films can show such client groups as: crisis or dysfunctional family, teens as a risk group, elderly people, people with special needs, orphans, homeless 
people, refugees, migrants, displaced persons and national minorities, unemployed, prisoners or people who returned from places of imprisonment, people with HIV and AIDS, alcohol and drug addicts, the military and people who are returning from combat zones [1]. These client groups are common in social cinema. Such films are based on sociopsychological problems of these groups, which form a main plot for the film.

Before to show social cinema to audience we need to define a target group for screening. Target group is an audience which socio-psychological states we as a specialists want to change by the film. For using social cinema, we want to define next target groups:

1.) clients of social work and their close environment;

2.) specialists who work with the client's social situation;

3.) students and young specialists who plan to work in the field of social work;

4.) society and certain risk groups.

Social work using social cinema will have its own goal and functional objectives with each of these target audiences.
We can say that the general purpose of watching social cinema with any of these audiences is to aware of existing of a social issue, to feel the problem as their own. This is an important remark, because social cinema does not solve social problems. It only focuses your attention on the problem and intensifies the necessity to solve it.

We divide target groups on primary and secondary groups. Primary groups include people that should be on the main focus of social work using social cinema. Society as a wide audience of social cinema, clients of social work and specialists of social work form primary target groups for social cinema screening. Secondary groups are also very important for social workers. It consists of risk groups of population, client's close environment and students. The social work with both groups should be combined and complex for better results. We reveal main functional tasks of social work with each target group and define methods of social work regarding to these tasks.

Table 2. Opportunities of using social cinema in social work

\begin{tabular}{|c|c|c|c|}
\hline Categories & Society & Clients & Specialists \\
\hline $\begin{array}{c}\text { Secondary } \\
\text { target audience }\end{array}$ & Risk groups & Client's close environment & Students and young specialists \\
\hline $\begin{array}{l}\text { Functional } \\
\text { tasks of the } \\
\text { cinema }\end{array}$ & $\begin{array}{l}\text { 1. To form kind and tolerant } \\
\text { relations between people. } \\
\text { 2. To increase awareness of } \\
\text { social issues and a necessity } \\
\text { to solve a problem. } \\
\text { 3. To prevent of stigmatized } \\
\text { and stereotyped relations in } \\
\text { society. }\end{array}$ & $\begin{array}{l}\text { 1. To show ways of solving } \\
\text { problems. } \\
\text { 2. To increase self-confidence } \\
\text { ("you are not alone with such } \\
\text { problem", "you can overcome } \\
\text { it"). } \\
\text { 3. To give an opportunity to see } \\
\text { a problem from the other side. }\end{array}$ & $\begin{array}{l}\text { 1. To give an understanding needs of client } \\
\text { groups. } \\
\text { 2. To give case situations for searching ways, } \\
\text { methods and forms of professional help. } \\
\text { 3. To show extreme situations for understanding } \\
\text { the behavior of some clients and for forming } \\
\text { ways of reactions and help in a safe way. } \\
\text { 4. To give an experience of successful solving } \\
\text { different social issues by other specialists. }\end{array}$ \\
\hline $\begin{array}{l}\text { Forms of } \\
\text { professional } \\
\text { work using } \\
\text { social cinema }\end{array}$ & $\begin{array}{c}\text { Preventing methods of } \\
\text { professional work. } \\
\text { The method of information } \\
\text { the population about some } \\
\text { social issues. }\end{array}$ & \begin{tabular}{|} 
Socio-psychological \\
rehabilitation, correctional work, \\
individual and group counseling \\
and training work with different \\
client groups and their close \\
environment.
\end{tabular} & $\begin{array}{l}\text { Educational forms of work: lectures, seminars, } \\
\text { master-classes, workshops, conferences, } \\
\text { educational cinema clubs. }\end{array}$ \\
\hline
\end{tabular}

Social cinema can be used in social work as a tool of prevention, informing, socio-psychological rehabilitation, counseling, training work and education. Social cinema can inform a population about actual social problems, form social consciousness, regulate public opinion and mood according to different social issues. Such function of social cinema helps to prevent stigmatization, stereotyped relations in society, addictions, teen pregnancy and bullying in teen groups.

In addition, social films can be shown for clients of social work and their close environment. Cinema gives for this target auditory an opportunity to see themselves from the other side, to see different ways of solving the problem. Social cinema can also perform a therapeutic and correctional function in professional work with client groups. Films can give people confidence, hope and belief in their happy future.

Students of social work and young specialists need to develop their skills and to get practice in a safe way. Social cinema can show students problems of different client groups, to study a situation, to analyze it and to build a strategy of social services aimed to help a client and to solve a problem. We can use films during lectures, seminars, workshops or conducting of educational cinema clubs with discussion social films with auditory.

In general, social cinema performs the following sociopsychological tasks:

- to inform about the existence of a social problem in society;

- to trigger a sense of urgency to solve the problem;

- to trigger a sense of solidarity, responsibility and involvement;

- to give a way of solving a problem.

The psychological mechanism of influence of social cinema on people is a problematization of the audience. Problematization means that people begin to aware social issue and to perceive the problems of others as their own after watching a social film.

Awareness of social cinema begins from feelings, than follow an understanding of social problem and planning or doing some actions to solve the problem. 
Table 3. An awareness of social problem by the audience of social cinema

\begin{tabular}{|c|c|c|}
\hline Feelings & Understanding & Actions \\
\hline $\begin{array}{l}\text { - The feeling of necessity to change social situation; } \\
\text { - The feeling of actuality and urgency of the problem; } \\
\text { - The feelings of solidarity and unity with the characters of the film; } \\
\text { - The feeling of your own responsibility and involvement into the } \\
\text { social issue; } \\
\text { - Being a member of the community; } \\
\text { - Social issue becomes your own problem, which you want to solve. }\end{array}$ & $\begin{array}{l}\text { - Analysis of the } \\
\text { surrounding social reality; } \\
\text { - Analysis of your own } \\
\text { behavior; } \\
\text { - Understanding of a new } \\
\text { information about the } \\
\text { unknown social issue; } \\
\text { - Fixing contradictions. }\end{array}$ & $\begin{array}{l}\text { - Change the attitude } \\
\text { to problem situation; } \\
\text { - Expansion of } \\
\text { representations about } \\
\text { social reality; } \\
\text { - Searching ways of } \\
\text { solving problem } \\
\text { situation. }\end{array}$ \\
\hline
\end{tabular}

Specialists can use different forms of work with the audience of social cinema. It can be individual or group exercises, that are more common. For such meetings specialists should organize a club environment with stable group of people, periodical meetings and discussions under the moderation of a specialist.

The screening of social film should has an introductory part that prepares the audience for watching, the part of watching a movie and discussion time.

Conclusions. Social cinema is a genre of cinematography, which highlights different social issues of social work client groups. Cinema has many advantages in highlighting social problems for audience.
Visual perception of information, modeling life situations and influence on a wide auditory help cinema to form social consciousness, to change public opinion and to solve actual social issues. Target audiences of watching social cinema are client groups of social work and their close environment, students and young specialists of social work, wide groups of a society and risk groups. Social cinema can be used in social work as a tool of prevention, informing, socio-psychological rehabilitation, counseling, training work and education.

Building of a concrete technology of social work using social cinema with separate client group will be a perspective of research.

\section{REFERENCES}

1. Beker M. The Screenwriter Activist: Writing Social Issue Movies» / Marilyn Beker. - New York: Taylor \& Francis, 2013. - $186 \mathrm{c}$.

2. Cosbey J. Using Contemporary Films to Teach about Social Problems / Janet Cosbey. // National Social Science Journal. April 2010, Vol. 34 Issue 1 - C. 53.

3. Friedman J. Performing Difference. Representations of 'The Other' in Film and Theatre / Jonatan C. Friedman. // University Press of America. , 2008. - 310 c.
4. Middleton R. Ethnic Prejudice and Susceptibility to Persuasion / Russell Middleton. // American Sociological Review., 1960. - C. 679-686.

5. Russell W. Teaching social issues with film / William B. Russell. - Charlotte, NC: Information Age Publishing, INC., 2009. - $181 \mathrm{c}$.

6. Sloan K. The Loud Silents: Origins of the Social Problem Film / Kay Sloan. // University of Illinois Press., 1988. - 14 c.

\section{Технологизация социального кино как инструмента социальной работы}

\section{М. Г. Мурадханян}

Аннотация. Статья исследует возможности и перспективы использования социального кино как инструмента социальной работы. Автор дает определение понятию «социальное кино», анализирует развитие феномена социального кино в историческом контексте. Данная статья исследует основные характеристики, типы и формы социального кино, его социально-психологическое влияние на различные клиентские группы социальной работы. Автор описывает место и практическое значение социального кино в социальной работе.

Ключевые слова: сочиальное кино, сочиальная работа, клиентские группы, население, инструмент социальной работы, технологизация. 